\title{
Motion Graphic Media Informasi Edukasi Penyakit Tuberculosis(TBC) Pada Klinik Karawaci Medika Tangerang
}

\author{
Gilang Kartika Hanum ${ }^{1}$, Arif Purwadi², Putra Rizky Aupahaq ${ }^{* 3}$ \\ ${ }^{1}$ Program Studi Sistem Informasi Fakultas Sains and Teknologi Universitas Raharja, ${ }^{2,3}$ Program \\ Studi Teknik Informatika Fakultas Sains and Teknologi Universitas Raharja \\ E-mail: ${ }^{1}$ gilanghanum@ raharja.info, ${ }^{2}$ arif.purwadih@raharja.info, ${ }^{* 3}$ putra.rizky@ raharja.info
}

\begin{abstract}
Abstrak
Tuberculosis atau yang lebih dikenal dengan penyakit TBC adalah penyakit yang disebabkan oleh kuman Mycobacterium Tuberculosis. Penyakit ini dapat diderita oleh siapa saja baik yang muda maupun yang tua. Klinik Karawaci Medika berlokasi di daerah Karawaci Tangerang merupakan klinik yang memberikan pelayanan kesehatan untuk perorangan dan karyawan perusahaan dengan menyediakan pelayanan medis dasar dan spesialis. Klinik Karawaci Medika sudah menangani berbagai macam penyakit salah satunya penyakit TBC. Saat ini masyarakat belum banyak mengetahui mengenai penyebaran dan akibat dari penyakit $T B C$ sehingga masyarakat yang terkena penyakit ini tiap tahun jumlahnya terus bertambah. Penyampaian informasi TBC yang berjalan saat ini di Klinik Karawaci Medika masih menggunakan media spanduk dan brosur. Media penyampaian tersebut kurang membuat masyarakat tertarik untuk mengetahui informasi tentang TBC masyarakat hanya membaca sekilas lalu membuang brosur yang sudah diberikan oleh klinik. Berdasarkan permasalahan yang ada maka dibuatlah video motion graphic tentang penyakit TBC sehingga dapat membantu pihak Klinik dalam menyampaikan informasi mengenai penyakit TBC.Metode yang digunakan dalam pembuatan media informasi berbasis multimedia adalah, metode pengumpulan data, perancangan media dan konsep produksi media. Aplikasi yang digunakan dalam penelitian ini adalah Adobe Premiere pro CS6, Adobe After Effect CS6, Adobe Photoshop CS6, Adobe Audition CS6, dan Adobe Media Encoder CS6. Hasil akhir berupa video informasi motion graphic edukasi kesehatan mengenai penyakit TBC.
\end{abstract}

Kata Kunci-Video, Informasi, Motion Graphic, TBC

\begin{abstract}
Tuberculosis or better known as TBC disease is a disease caused by the bacteria Mycobacterium Tuberculosis. This disease can be suffered by anyone, both young and old. Karawaci Medika Clinic, located in the Karawaci area of Tangerang, is a clinic that provides health services for individuals and company employees by providing basic and / or specialist medical services. Karawaci Medika Clinic has handled various diseases, one of which is TBC. Currently, people do not know much about the spread and consequences of TBC disease so that the number of people affected by this disease continues to grow every year. The current TB information delivery at the Karawaci Medika Clinic is still using banners and brochures. The delivery media did not make the public interested in knowing information about TB. The community only read briefly and then threw away the brochures that had been given by the clinic. Based on the existing problems, a motion graphic video about TBC was made so that it could help the Karawaci Medika Clinic in conveying information about TB disease. The method used in making multimedia-based information media is data collection methods, media design and the concept of media production. The applications used in this research are Adobe Premiere pro CS6, Adobe After Effects CS6, Adobe Photoshop CS6, Adobe Audition CS6, and Adobe Media Encoder CS6. The final result is a video information motion graphic health education about $T B C$.
\end{abstract}

Keywords-Video, Information, Motion Graphics, Tuberculosis 


\section{PENDAHULUAN}

[1] Motion graphic merupakan salah satu cabang ilmu desain grafis, dimana dalam motion, elemen - elemen desain seperti bentuk, raut, ukuran, arah, tekstur yang terdapat di dalamnya, dengan secara sengaja digerakkan atau diberi pergerakan agar tampak hidup [2] dan Media berada diambang revolusi digital, yang akan menggabungkan komunikasi, penyiaran dan industri komputer. Kecepatan dan variasi komunikasi akan meningkat sangat pesat. Mereka akan meningkatkan akses ke semua bentuk media dan mengurangi dampak organisasi yang kuat, seperti yang biasa di Amerika Serikat sehingga [3] Suatu informasi dikatakan bernilai apabila manfaat yang diperoleh lebih efektif dibandingkan dengan biaya untuk mendapatkannya.

[4] Virus sangat dikenal sebagai penyebab penyakit infeksi pada manusia dan tumbuhan. Sejauh ini tidak ada makhluk hidup yang tahan terhadap virus. Tiap virus secara khusus menyerang sel-sel tertentu pada inangnya. Virus yang menyebabkan selesma menyerang saluran pernapasan, virus campak menginfeksi kulit, virus hepatitis menginfeksi hati, virus rabies menyerang sel-sel saraf. [5] Tuberkulosis merupakan penyakit infeksi yang menyerang parenkim paru dan disebabkan oleh Mycobacterium Tuberculosis, penyakit ini sangat mudah sekali dalam penularannya, karena penyebarannya melalui udara. Penyakit tuberkulosis sangat mematikan apabila tidak segera dilakukan penanganan.

Klinik Karawaci Medika melayani beragam pasien terutama dalam penyakit TBC (tuberculosis), video informasi sebagai salah satu upaya dalam memberikan edukasi dan informasi bidang kesehatan baik terhadap pasien klinik maupun pengunjung yang sedang menunggu di ruang tunggu klinik. Upaya ini dilakukan sebagai media informasi dalam bidang kesehatan khususnya informasi mengenai penyakit yang sering atau yang sedang dialami oleh masyarakat.

\section{METODE PENELITIAN}

\section{1. $\quad$ Metode Pengumpulan Data}

Untuk mendapatkan data yang diperlukan sebagai bahan penulisan laporan penelitian, penulis membutuhkan beberapa metode, antara lain :

1. Observasi (Observation Research)

2. Wawancara (Interview)

3. Studi Pustaka

\subsection{Analisis SWOT}

[6] Analisis SWOT didasarkan pada logika yang dapat memaksimalkan kekuatan (strengths), dan peluang (opportunity), namun secara bersamaan dapat meminimalkan kelemahan (weaknesses), dan ancaman (threat). Proses pengambilan keputusan strategis selalu berkaitan dengan pengembangan misi, tujuan strategis, dan kebijakan perusahaan. Perencanaan strategis harus menganalisis faktor - faktor strategis perusahaan (kekuatan, kelemahan, peluang, dan ancaman) dalam kondisi yang ada saat ini

\subsection{Perancangan Media}

Pembuatan video informasi edukasi kesehatan pada Klinik Karawaci Medika ini merupakan media penunjang informasi seputar edukasi untuk pasien atau masyarakat yang dirancang berdasarkan kebutuhan yang diajukan stakeholder khususnya pegawai internal klinik, yang selanjutnya dirancang menggunakan aplikasi program komputer grafis. Adapun aplikasi 
yang digunakan adalah Adobe Premiere pro CS6, Adobe After Effect CS6, Adobe Photoshop CS6, Adobe Audition CS6, dan Adobe Media Encoder CS6.

\section{HASIL DAN PEMBAHASAN}

\subsection{Pre-Production}

[7] Pre-Production merupakan step atau langkah awal dimulainya suatu karya diantaranya ide, perencanaan, dan persiapan dari Konsep Produksi Media. Terdapat sepuluh langkah pre-production dalam Konsep Produksi Media, dimulai dari ide yang dituangkan secara sistematis, lalu kemudian pembuatan sinopsis, narasi, storyboard, script writing, rundown, penyusunan crew, semua tahapan yang ada harus sesuai time schedule yang ditetapkan, kemudian menyusun anggaran / budget, dan peralatan yang digunakan.

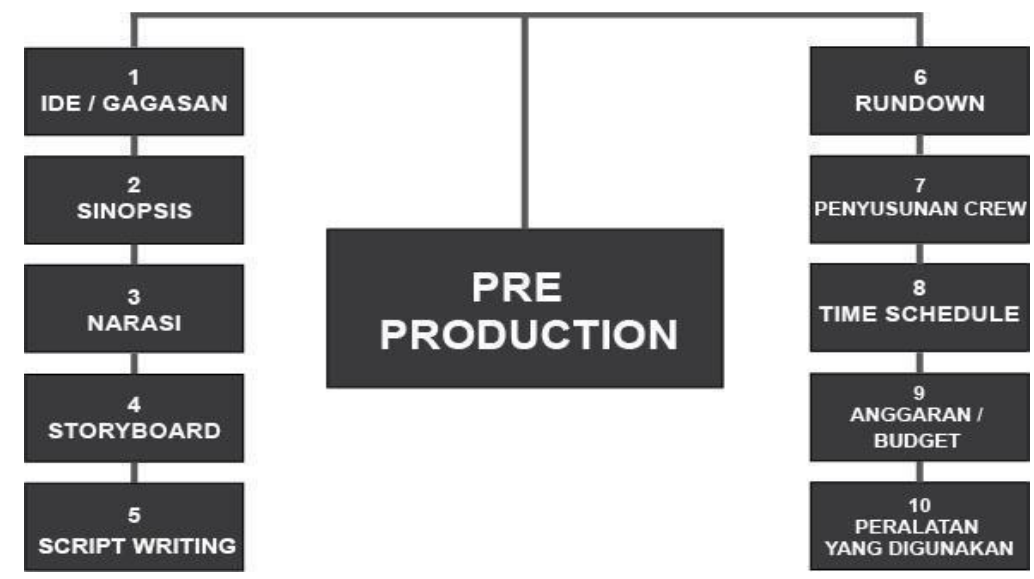

Gambar 1. Pre-Production

\subsubsection{Ide atau Gagasan}

Ide atau Gagasan merupakan sebuah rencana awal dari proses pre-production, hal itu merupakan hal yang mendasar untuk perancangan sebuah karya video. Sebuah ide atau gagasan yang telah tercipta kemudian dikembangkan lagi dengan mengumpulkan data - data berdasarkan masalah yang ada. Kemudian dalam penelitian ini konsep yang dibutuhkan dalam perancangan video motion graphic akan menjelaskan tentang penyakit dan cara hidup sehat, diantaranya informasi penyakit Tuberculosis (TBC), informasi penyebab Tuberculosis (TBC), dan informasi pencegahan Tuberculosis (TBC) dengan konsep yang menarik agar dapat meningkatkan kesadaran masyarakat akan hidup sehat.

\subsubsection{Sinopsis / Cerita}

Sinopsis merupakan rangkuman sebuah cerita dari ide yang telah dikembangkan menjadi bentuk ringkasan dari perancangan awal sebuah video yang bertujuan agar pembaca memiliki gambaran sekilas dari isi, sehingga memberikan garis besar sebagai acuan pokok improvisasi.

\subsubsection{Narasi}

Narasi adalah representasi dari peristiwa - peristiwa atau rangkaian dari peristiwa peristiwa. Narasi juga dapat memperjelas alur cerita dari video yang disampaikan. 


\subsubsection{Pembuatan Storyboard}

Storyboard adalah visualisasi susunan sketsa gambar sketsa secara bertahap, disusun sesuai dengan alur cerita untuk kepentingan shooting ataupun pengambilan gambar saat produksi. Pembuatan storyboard sangatlah sulit namun akan memudahkan pengambilan gambar saat proses produksi agar para audiensdan pengunjung lebih mudah memahami informasi yang disampaikan di dalam video tersebut. Berikut storyboard perancangan video motion graphic informasi penyakit $T B C$ pada Klinik Karawaci Medika :

Scene 1

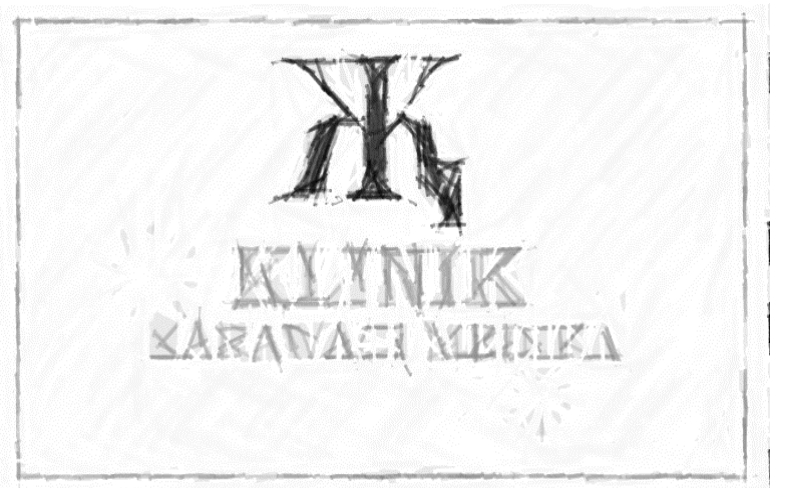

Gambar 2.

Menampilkan video animasi logo Klinik Karawaci Medika

Scene 2

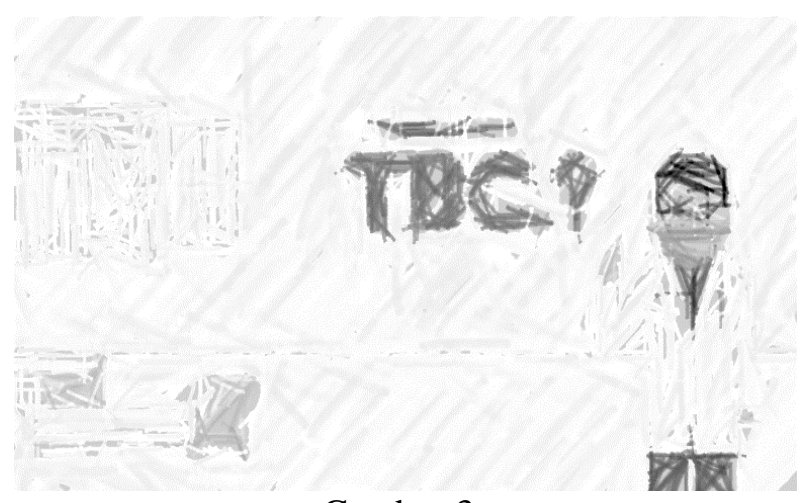

Gambar 3.

Menampilkan video animasi pertanyaan apa itu penyakit $T B C$ ?

Scene 3

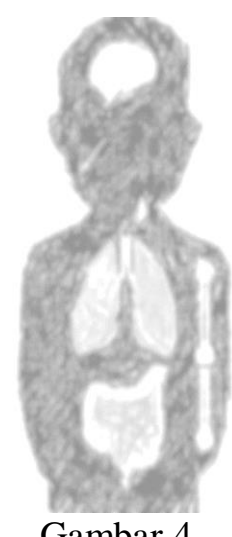

Menampilkan video animasi penjelasan mengenai penyakit $T B C$ 
Scene 4

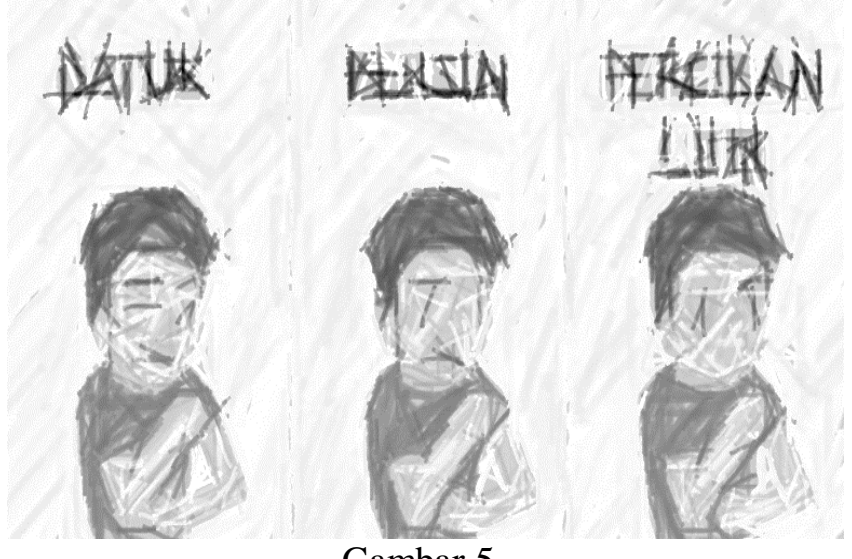

Gambar 5 .

Menampilkan video animasi tanda gejala umum orang yang terkena penyakit $T B C$

Scene 5

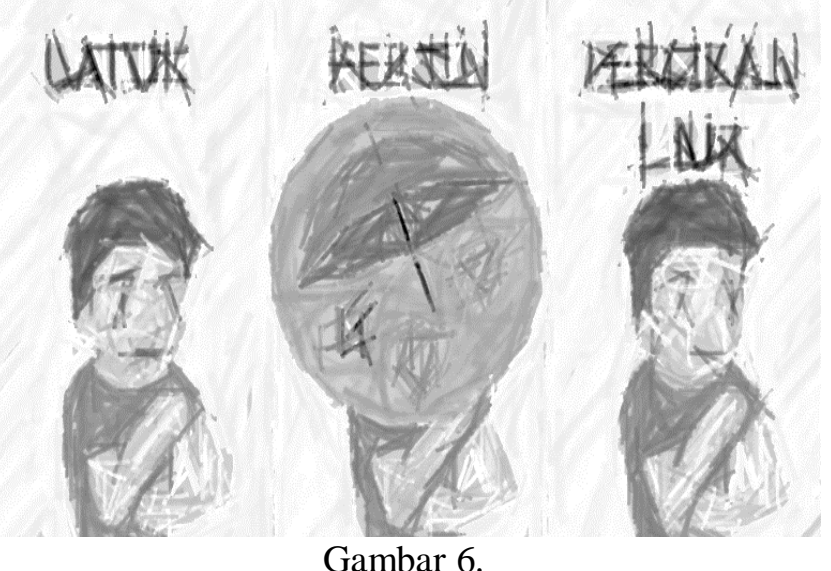

Menampilkan video animasi virus dapat berkembang di udara lembab dan tidak ada matahari

Scene 6

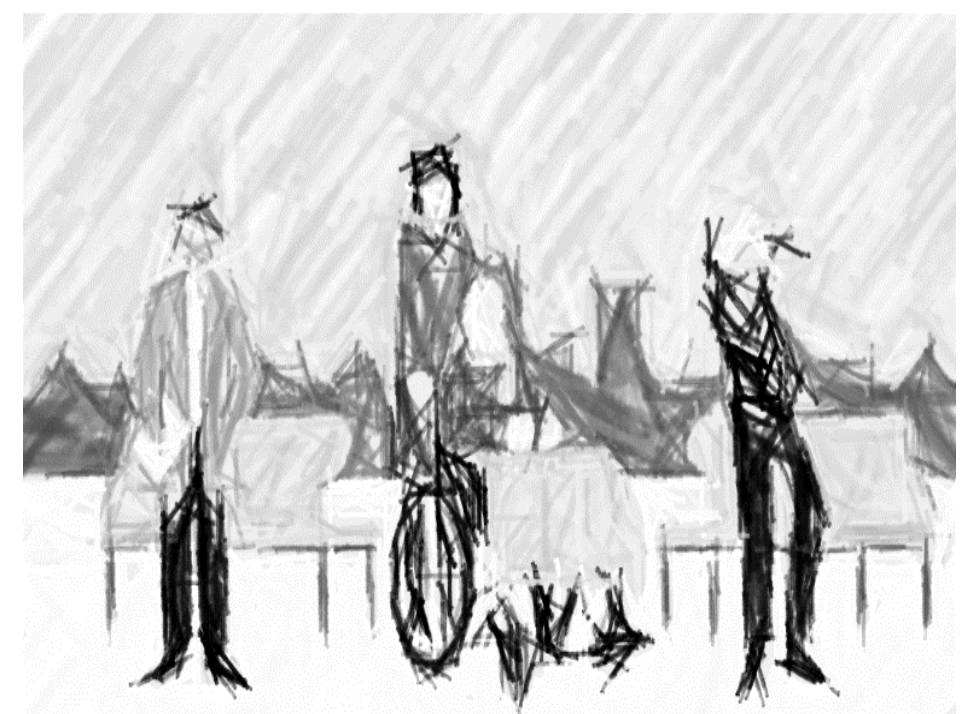

Gambar 7.

Menampilkan video animasi siapa saya orang yang rentan terkena penyakit $T B C$ 
Scene 7

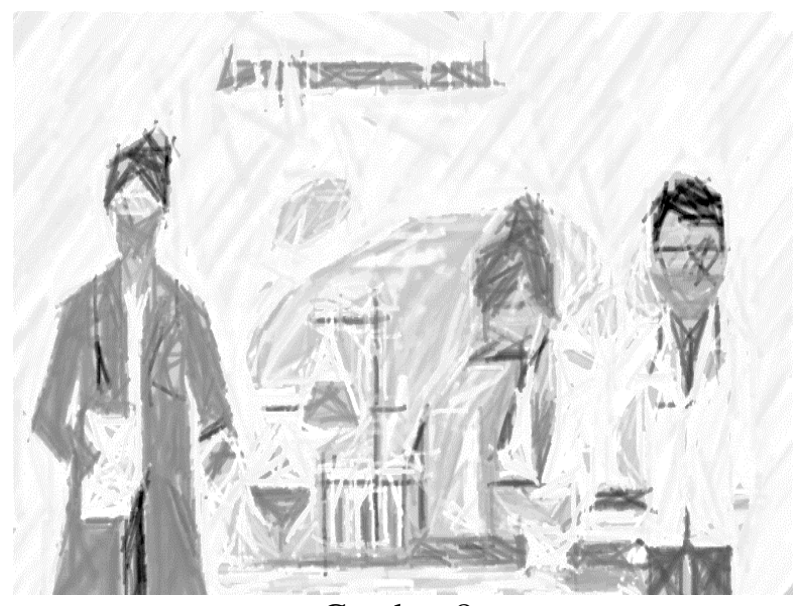

Gambar 8 .

Menampilkan video animasi apakah penyakit $T B C$ dapat disembuhkan?

Scene 8

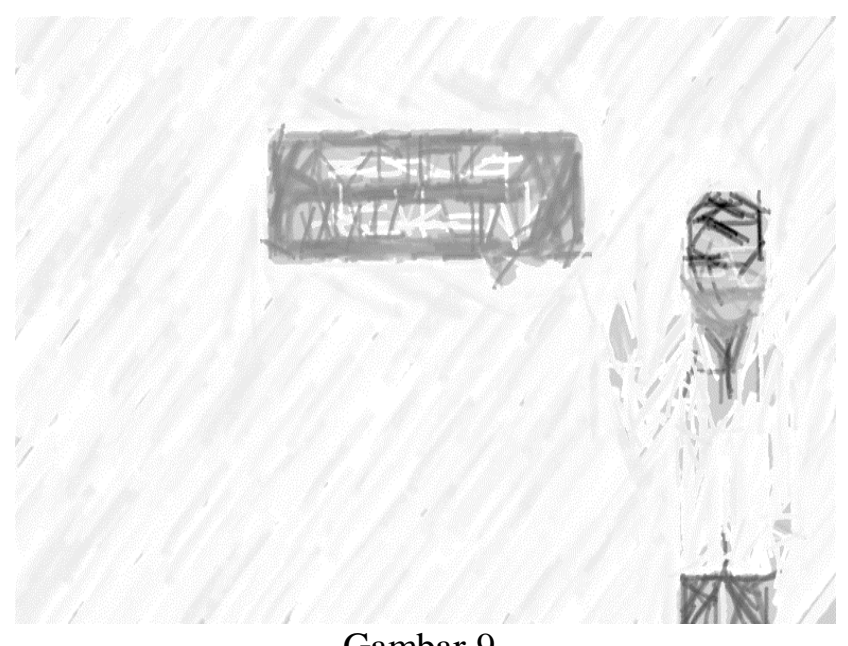

Gambar 9.

Menampilkan video animasi langkah - langkah untuk pencegahan penyakit $T B C$

Scene 9

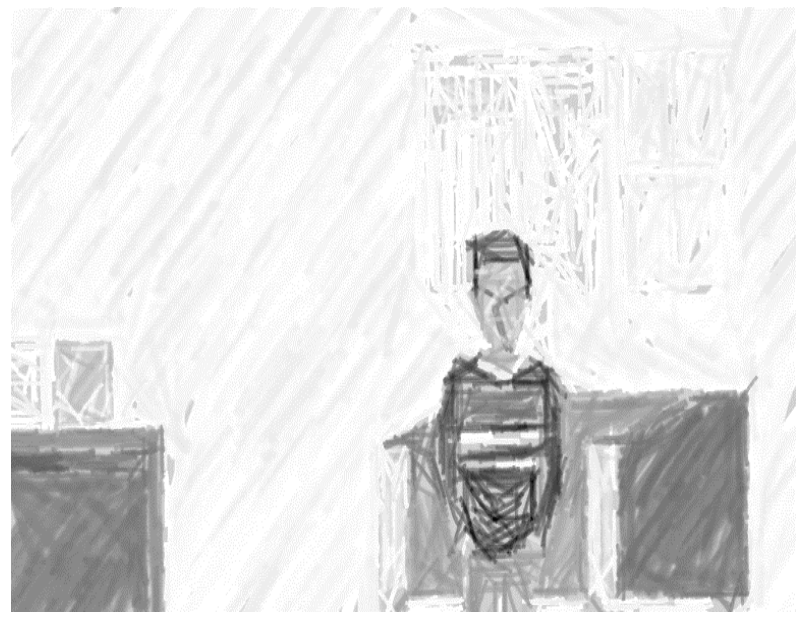

Gambar 10.

Menampilkan video animasi informasi dari radio mengenai penyakit $T B C$ 
Scene 10

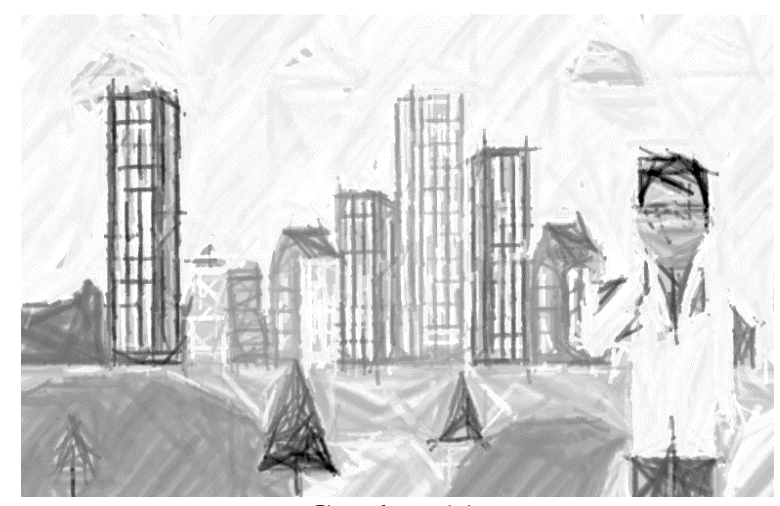

Gambar 11.

Menampilkan video animasi langkah - langkah untuk membantu orang yang terkena penyakit $T B C$ untuk merujuk ke rumah sakit terdekat

Scene 11

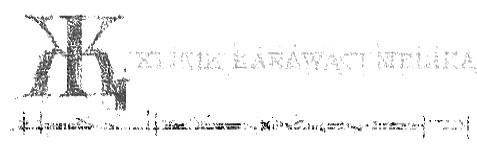

Gambar 12.

Menampilkan video animasi penutup motion graphic dengan gambar logo dan alamat Klinik Karawaci Medika.

\subsection{Production}

Production atau produksi merupakan proses pengambilan gambar atau shooting video dengan bekerjasama antara para kru dan pemain untuk mewujudkan rumusan dari tahap pra produksi dalam bentuk skenario, naskah dan storyboard yang telah direncanakan. Pada tahap produksi semua unsur teknis dan kreatif dijalankan dibawah pengawasan director atau sutradara. Mencapai semua tujuan pada tahap produksi ini diperlukannya proses perancangan multimedia, perancangan audio, perancangan visual dan perancangan broadcasting.

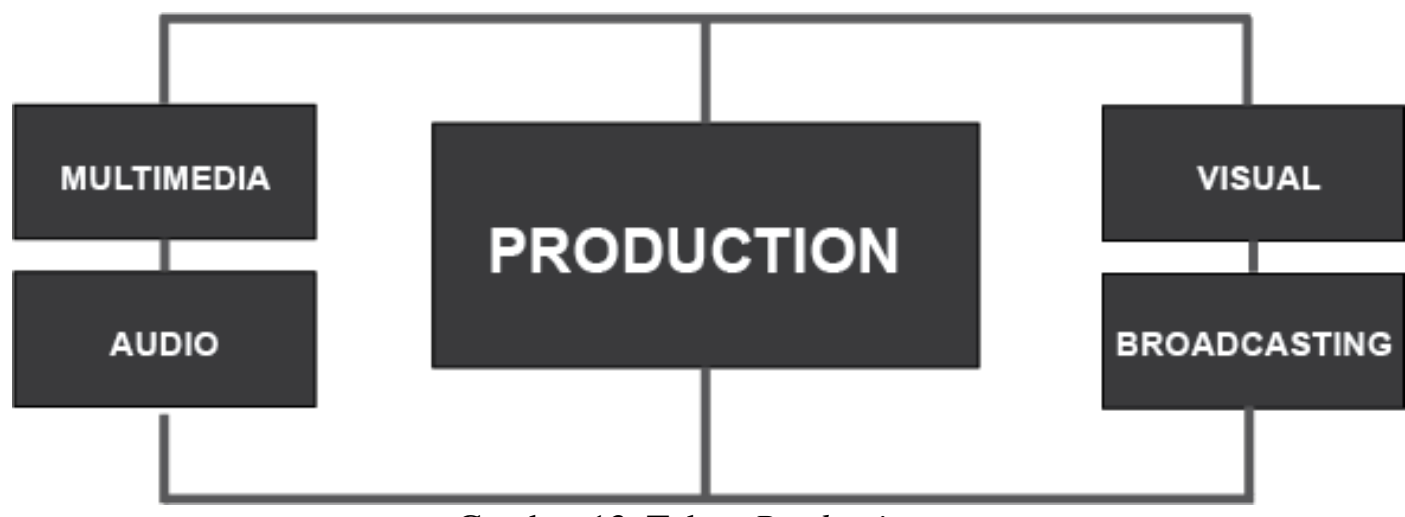

Gambar 13. Tahap Production 


\subsection{Post-Production}

Post-Production ialah melakukan tahap akhir dari penyelesaian dalam sebuah karya yang dimana berawal dari karya mentah menjadi sebuah video yang utuh dan sempurna dan mampu menceritakan pesan dan informasi di dalamnya dengan menarik kepada audience. Di dalam proses post-production diperlukannya beberapa tahapan seperti Digitizing, Editing, Mixing, Finishing, Exporting dan Segmen Pasar.

Scene 1

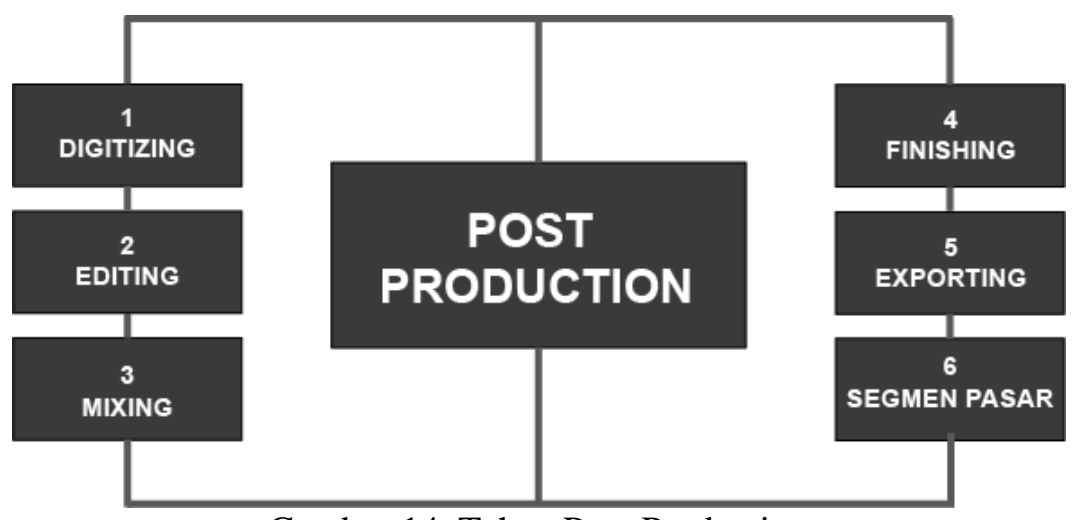

Gambar 14. Tahap Post-Production

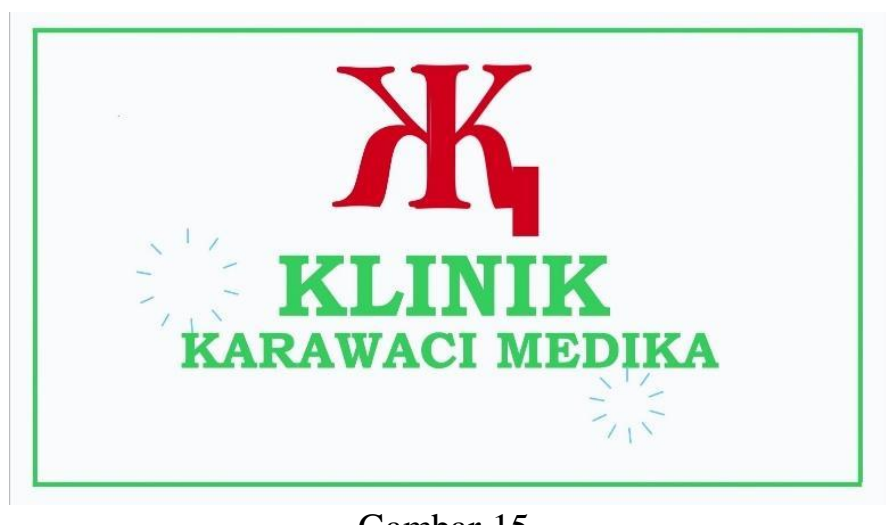

Gambar 15.

Menampilkan video animasi logo Klinik Karawaci Medika

Scene 2

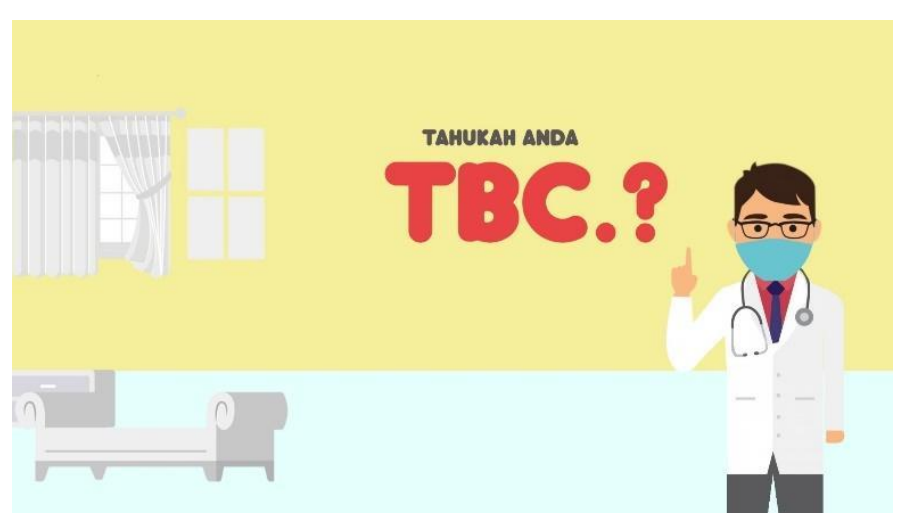

Gambar 16.

Menampilkan video animasi pertanyaan apa itu penyakit $T B C$ ? 
Scene 3

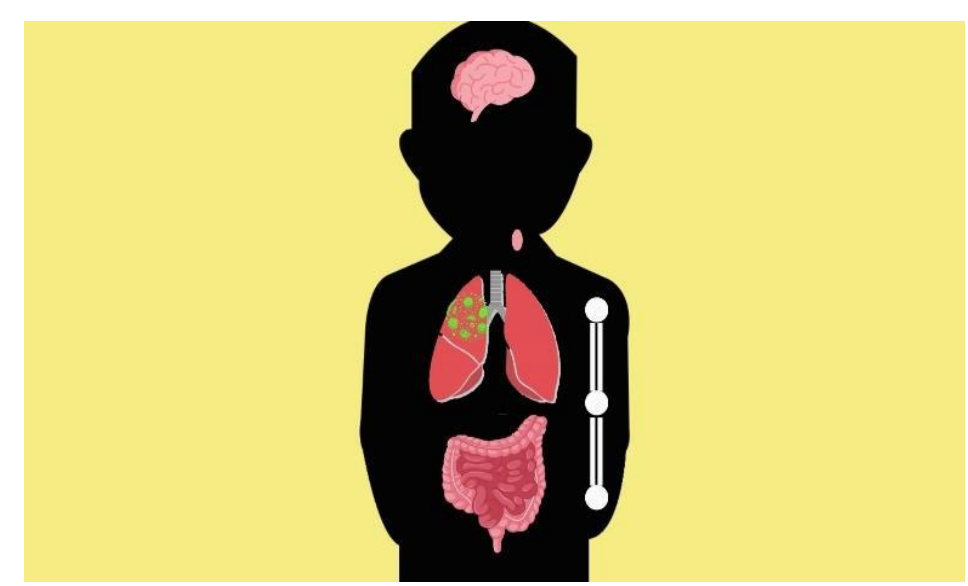

Gambar 17.

Menampilkan video animasi penjelasan mengenai penyakit $T B C$

Scene 4

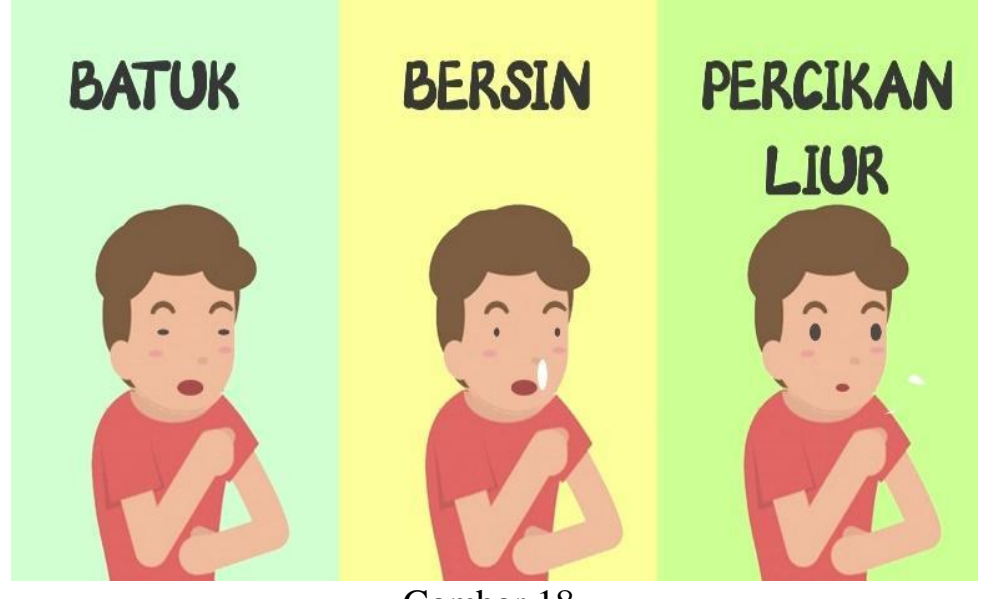

Gambar 18.

Menampilkan video animasi tanda gejala umum orang yang terkena penyakit $T B C$

Scene 5

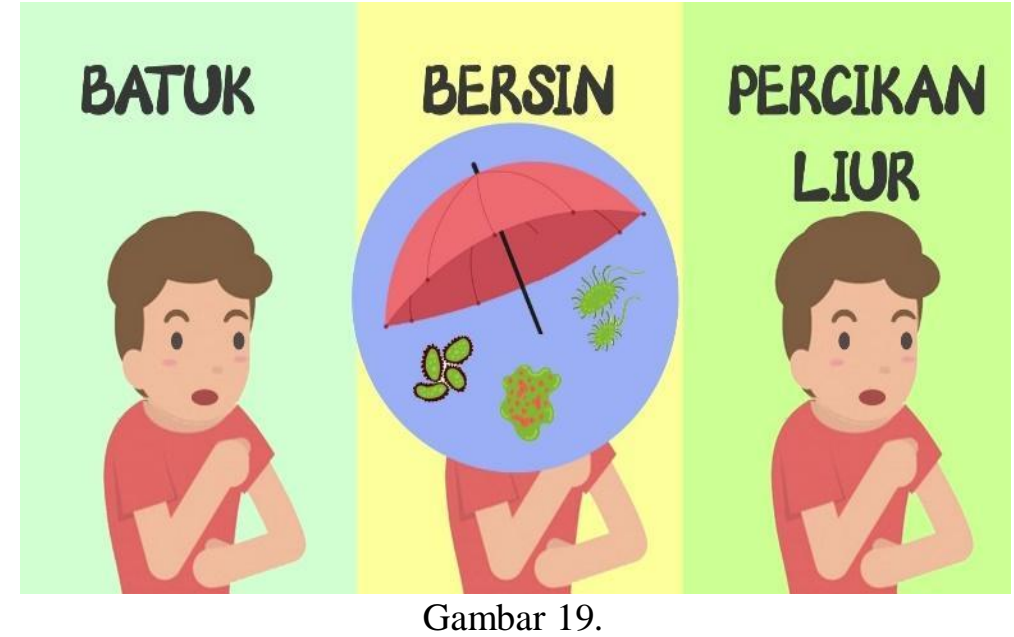

Menampilkan video animasi virus dapat berkembang di udara lembab dan tidak ada matahari 
Scene 6

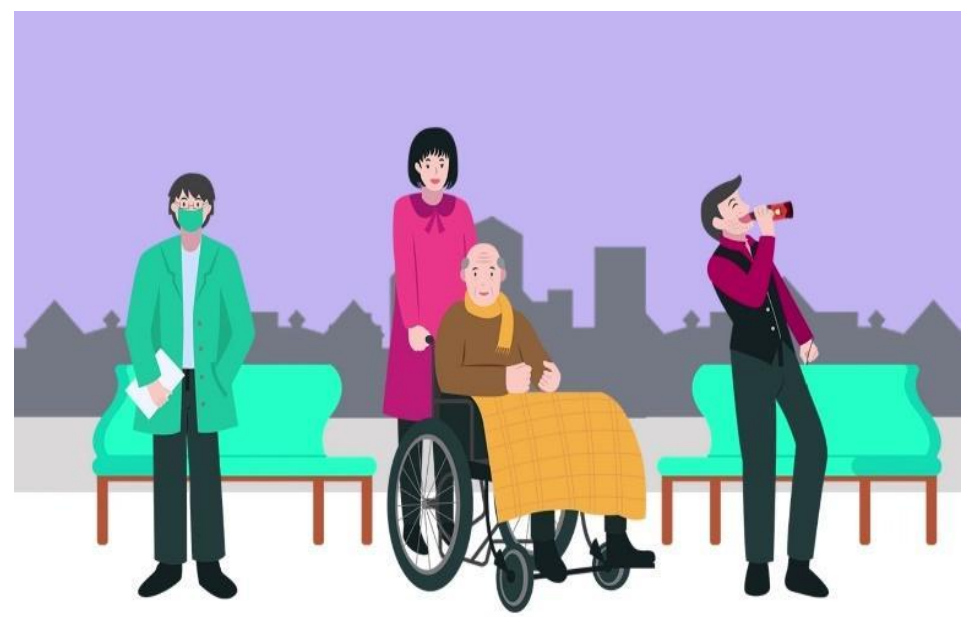

Gambar 20.

Menampilkan video animasi siapa saya orang yang rentan terkena penyakit $T B C$

Scene 7

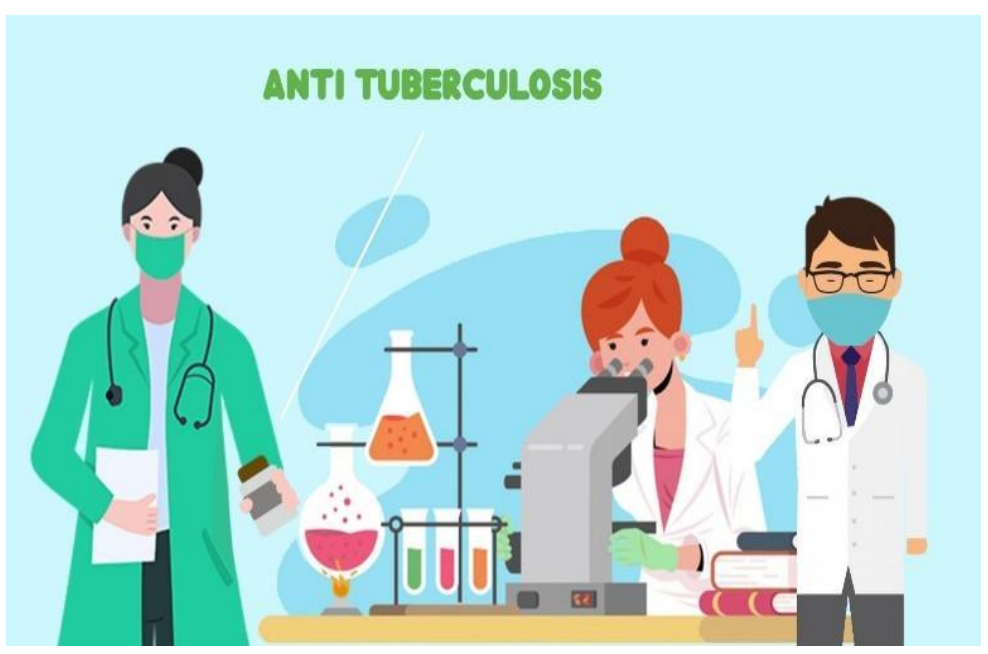

Gambar 21.

Menampilkan video animasi apakah penyakit $T B C$ dapat disembuhkan?

Scene 8

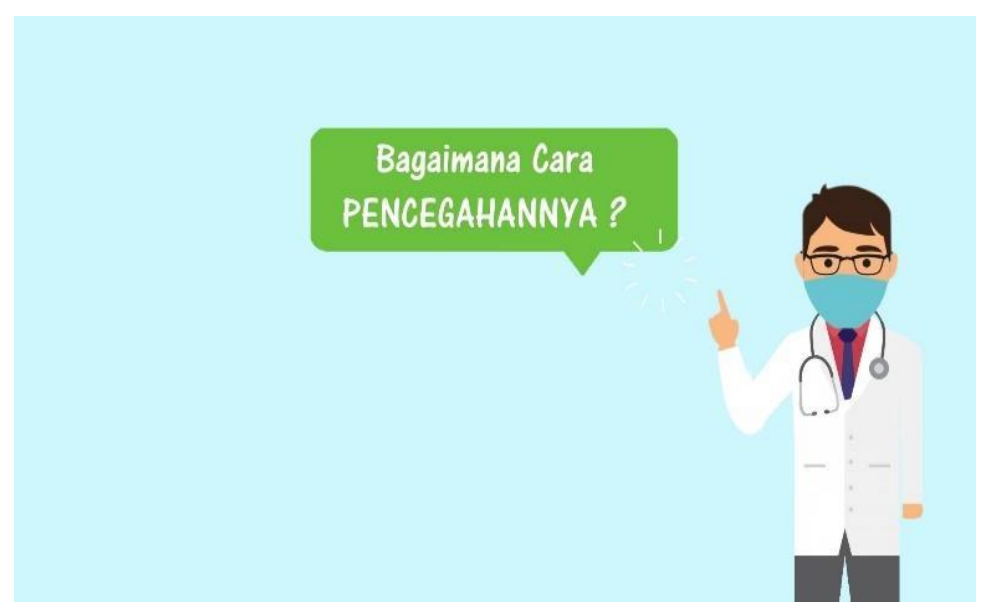

Gambar 22.

Menampilkan video animasi langkah - langkah untuk pencegahan penyakit TBC 
Scene 9

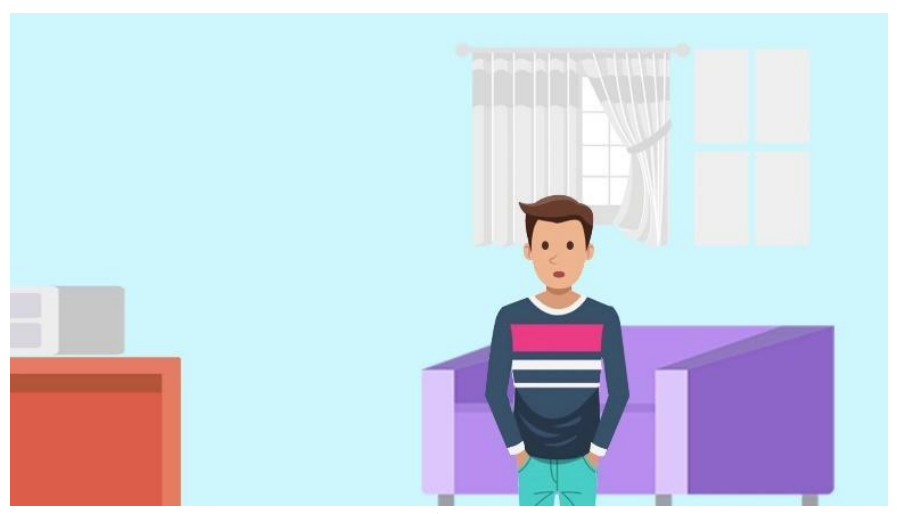

Gambar 23.

Menampilkan video animasi informasi dari radio mengenai penyakit $T B C$

Scene 10

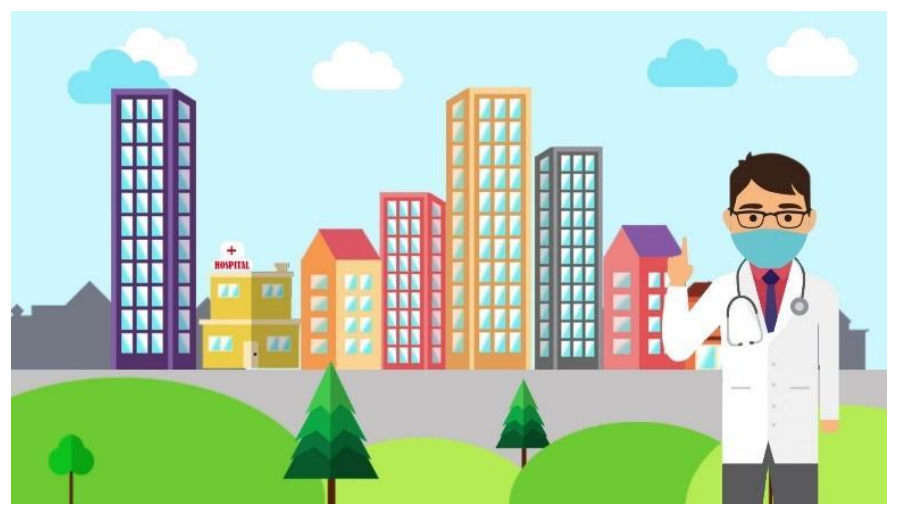

Gambar 24.

Menampilkan video animasi langkah - langkah untuk membantu orang yang terkena penyakit $T B C$ untuk merujuk ke rumah sakit terdekat

Scene 11

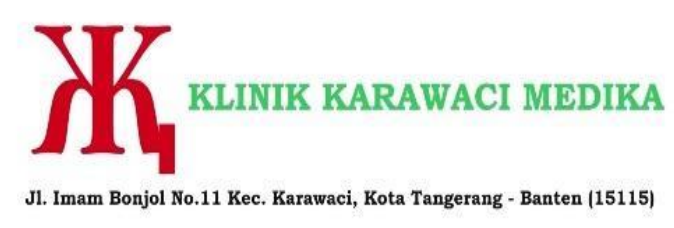

Gambar 25.

Menampilkan video animasi penutup motion graphic dengan gambar logo dan alamat Klinik Karawaci Medika. 


\section{KESIMPULAN}

Kesimpulan terhadap rumusan masalah mengenai perancangan media video ini yaitu memberikan informasi penyakit Tuberculosis $(T B C)$ dan memberikan informasi pencegahannya melalui strategi berbentuk video motion graphic pada layar televisi di ruang tunggu pasien. Untuk merancang video informasi yang menarik mengenai penyakit Tuberculosis (TBC) dan cara pencegahannya pada Klinik Karawaci Medika pada penelitian ini penulis membuat video motion graphic yang berisi informasi mengenai penyakit $T B C$ dan bagaimana cara untuk pencegahannya.. Untuk membangun persepsi atau pola pikir masyarakat mengenai penyakit Tuberculosis $(T B C)$ dengan baik dibutuhkan adanya informasi mengenai bahayanya terkena penyakit $T B C$ dengan menjelaskan gejala jika terkena penyakit TBC seperti adanya flek di paruparu, batuk disertai darah, suhu tubuh diatas $38^{\circ} \mathrm{C}$, penurunan berat badan, demam dan keluar keringat tanpa aktivitas.

\section{SARAN}

Berdasarkan hasil penelitian yang telah disimpulkan, terdapat beberapa saran untuk Klinik Karawaci Medika Tangerang diantaranya : Klinik Karawaci Medika dapat lebih aktif memberikan informasi kesehatan mengenai Tuberkulosis (TBC) untuk tetap menjaga kesehatan yang ada di masyarakat umum agar memperkecil resiko penularan Tuberkulosis (TBC). Klinik Karawaci Medika dapat mengedukasi lebih luas tentang kesehatan mengenai Tuberkulosis $(T B C)$ untuk masyarakat luas melalui media informasi seperti media cetak maupun media sosial berbentuk video dan berharap perancangan media video ini akan ada penelitian dan pengembangan selanjutnya menyesuaikan dengan informasi yang telah update dengan penyajian yang lebih menarik dan mudah dipahami audiens, sehingga bermanfaat untuk masyarakat luas.

\section{DAFTAR PUSTAKA}

[1] Umam, N. C. (2016) Perancangan Motion Graphic Pengenalan Batik Gemawang Karya Khas Kabupaten Semarang. [Jurnal]. Fakultas Seni Rupa, Institut Seni Yogyakarta.

[2] Crane, Diana. Kawashima, Nobuko, KawasakiandKen'ichi. 2016. Global Culture : Media, Arts, Policy, andGlobalization. New York : Routledge

[3] Rahayu, Sri, Zainul Hakim, and Masitoh Masitoh. "Sistem Informasi Pengendalian Persediaan Bahan Baku Material Mentah." JURNAL SISFOTEK GLOBAL 9.1 (2019).

[4] Kuswiyanto (2018). Virologi, Pusat pendidikan sumber daya manusia kesehatan, Jurnal Bahan Ajar Teknologi Laboratorium Medik, Kementerian Kesehatan Republik Indonesia. Diakses: 06 Desember 2020. Jurnal.

[5] Iwan, D. Ambo, Heriansyah, P. Imran (2019). GAMBARAN MOTIVASI KELUARGA DALAM PENCEGAHAN PENULARAN TUBERKULOSIS PARU DI RUMAH SAKIT UMUM DAERAH SINJAI,Makassar :Politeknik Kesehatan Makassar, Jurnal Media Keperawatan vol 10, No 1, E-ISSN : 2622-0148, P-ISSN : 2087-0035 Sumber: http://journal.poltekkes-

mks.ac.id/ojs2/index.php/mediakeperawatan/article/download/110/pdf . Diakses: 29 November 2020. Jurnal 
[6] Sunaryo dan Rusdarti. 2017. Analisis SWOT Untuk Menetapkan Strategi Bersaing Pada PT. Tarindo. Semarang: Universitas Negeri Semarang. Economics Development Analysis Journal.ISSN:2252-6965.Vol.6,No.1: 88.

[7] Wibowo,Edi.DewiPopiRomika,danMegaCutRyana.2017.Perancangan Video Profile Sebagai Penunjang Media Informasi Dan Promosi Pada SMA Citra Islami Tangerang.Yogyakarta: Journal Seminar Nasional Teknologi Informasi Dan Multimedia STMIK AMIKOM. Vol.5 No. $1: 65$. 